\title{
Gambaran Penggunaan Alat Pelindung Diri oleh Perawat di Ruang Perawatan Rumah Sakit
}

\author{
Devi Nurmalia ${ }^{1,}{ }^{*}$, Sarah Ulliya ${ }^{1}$, Linawati Neny ${ }^{2}$, Agnes Agustina Hartanty ${ }^{1}$ \\ ${ }^{1}$ Departemen Ilmu Keperawatan Fakultas Kedokteran, Universitas Diponegoro, Semarang, Indonesia \\ ${ }^{2}$ Infection Prevention and Control Nurse (IPCN) Rumah Sakit Dokter Kariadi, Semarang, Indonesia \\ devinurmalia@fk.undip.ac.id
}

\begin{abstract}
Introduction: Health Care Associated Infection (HAIs) is a major problem faced throughout the world and this incident continues to increase. The use of Personal Protective Equipment (PPE) of nurses is inadequate. Previous studies have not yet described how the suitability of PPE use with the actions taken by nurses. Therefore, in this study will be described how the use of PPE by nurses. The study aimed to identify nurse compliance in using PPE.

Methods: This was a descriptive analytic and observation method for data collection. The sample in this study was an action carried out by nurses, in this case the nurse was observed to suit the use of PPE with Standard Operating Procedure (SPO) in the hospital. The sampling technique used was accidental sampling towards 67 actions of PPE using observation sheet according to hospital SPO. Data is processed univariately and presented in the form of frequency distribution.

Results: The result showed that, PPE most frequently used in general ward that is gloves, mask, and also apron. The results showed that as many as 54,39\% of actions taken by nurses were inappropriate in the use of glove. The use of masks and apron among the nurses is almost entirely correct, only 1 mask error was found.

Conclusion: PPI through Infection Prevention Control Nurse (IPCN) should provide socialization and information on the use of PPE in accordance with hospital standard operational procedure. IPCN is expected to be an appropriate role model in the use of PPE, while the head nurse provides motivation and spirit to the nurses to be more compliant in the procedure when using gloves.
\end{abstract}

Keywords: Apron, Gloves, Infection control, Mask, PPE

\section{Abstrak}

Pendahuluan: Risiko infeksi nosokomial (HAIs) merupakan masalah besar yang dihadapi di seluruh dunia dan kejadian ini terus meningkat. Penggunaan Alat Pelindung Diri (APD) pada perawat masih dikategorikan kurang. Penelitian sebelumnya belum menggambarkan kesesuaian penggunaan APD dengan tindakan yang dilakukan perawat. Penelitian ini bertujun untuk mengidentifikasi gambaran pemakaian APD di ruang perawatan di rumah sakit.

Metode: Penelitian merupakan penelitian deskriptif dengan metode observasi untuk pengambilan data. Sampel pada penelitian ini adalah tindakan yang dilakukan perawat, dalam hal ini perawat diamati kesesuaian penggunaan APD dengan SOP yang ada di rumah sakit. Teknik sampling yang digunakan adalah accidental sampling pada 67 tindakan penggunaan APD menggunakan lembar observasi sesuai SOP. Data diolah secara univariat dan disajikan dalam bentuk distribusi frekuensi. 
Hasil: APD yang paling sering digunakan yaitu sarung tangan, masker, dan juga apron. Hasil penelitian menunjukkan bahwa sebanyak 54,39\% tindakan yang dilakukan perawat tidak sesuai dalam penggunaan sarung tangan. Penggunaan masker dan apron di antara perawat sudah hampir seluruhnya benar, hanya ditemukan satu kesalahan pemakaian masker.

Saran: PPI melalui Infection Prevention Control Nurse (IPCN) sebaiknya memberikan sosialisasi dan informasi penggunaan APD sesuai SOP rumah sakit. IPCN diharapkan menjadi role model yang tepat dalam penggunaan APD, sementara kepala ruang dapat memberikan motivasi dan semangat perawat untuk lebih patuh dalam menggunakan sarung tangan yang sesuai prosedur.

Kata kunci: APD, Apron, Masker, Pengendalian infeksi, Sarung tangan

\section{PENDAHULUAN}

Rumah sakit (RS) merupakan sumber infeksi bagi petugas kesehatan, pasien dan juga pengunjung. Risiko infeksi di rumah sakit dikenal dengan istilah infeksi nosokomial merupakan masalah kesehatan global. Infeksi terkait pelayanan kesehatan atau Healthcare Associated Infection (HAIs) merupakan salah satu masalah global termasuk di Indonesia. World Health Organization (WHO) menunjukkan bahwa prevalensi kejadian HAIs pada pasien sebesar 7\% di negara maju dan $10 \%$ di negara berkembang terjadi setiap tahunnya (WHO, 2016). Centre for Disease Control and Prevention (CDC) menyebutkan bahwa infeksi ini terus meningkat di berbagai negara (CDC, 2015). Kejadian infeksi nosokomial di sepuluh RS Indonesia tahun 2010 cukup tinggi yaitu $6-16 \%$ dengan rata-rata $9,8 \%$. Infeksi nosokomial paling umum terjadi adalah infeksi luka operasi (ILO). Hasil penelitian terdahulu menunjukkan bahwa angka kejadian ILO pada RS di Indonesia bervariasi antara 2-18\% dari keseluruhan prosedur pembedahan (Jeyamohan, 2010). Kejadian infeksi nosokomial yang terjadi di RSUD Setjonegoro dari bulan Juli 2009 sampai Desernber 2011 yang terbanyak adalah plebitis, ILO, dan dekubitus (Nugraheni, Suhartono, \& Winarni, 2012).
HAIs merupakan penyebab signifikan penyakit dan kematian yang memiliki konsekuensi secara emosional, finansial dan medis. Sekitar satu dari 25 pasien rawat inap per tahunnya memiliki infeksi terkait dengan perawatan di rumah sakit yang menyebabkan kematian dan kerugiaan biaya perawatan kesehatan di rumah sakit (CDC, 2015)

Sasaran keselamatan pasien yang kelima adalah menurunkan risiko HAI's. Petugas kesehatan merawat pasien bukan untuk mendapatkan masalah, pengunjung datang untuk memberikan support kepada pasien bukan untuk menjadi pasien baru. Pasien pulang dengan keadaan sembuh bukan untuk mendapatkan infeksi tambahan (Loveday, Lynam, Singleton, \& Wilson, 2014).

Salah satu upaya yang dilakukan oleh rumah sakit untuk mencegah dan menekan kejadian infeksi adalah dengan membentuk tim Pencegahan dan Pengendalian Infeksi (PPI). Peraturan Menteri Kesehatan nomor 27 tahun 2017 menyatakan bahwa PPI berperan dalam melakukan perencanaan, pelaksanaan, pembinaan, pendidikan, pelatihan, serta monitoring dan evaluasi terkait HAIs. Beberapa bentuk infeksi rumah sakit (HAIs) yang sering ditemukan diantaranya adalah Ventilator Associate Pneumoni 
(VAP), Infeksi Aliran Darah Pusat (IADP), Infeksi Saluran Kemih (ISK), Infeksi Daerah Operasi (IDO), Infeksi Luka Infus (ILI) dan infeksi lainnya (Kementerian Kesehatan Republik Indonesia [Kemenkes $\mathrm{RI}], 2017$ ).

Kewaspadaan standar adalah kewaspadaan dalam pencegahan dan pengendalian infeksi rutin dan harus diterapkan terhadap semua pasien di semua fasilitas kesehatan. Kewaspaaan standar ini dirancang untuk mengurangi risiko terinfeksi penyakit menular pada petugas kesehatan baik dari sumber infeksi yang diketahui ataupun yang tidak diketahui (Kemenkes RI, 2017; WHO, 2016).

Salah satu dari kewaspadaan standard adalah penggunaan Alat Pelindung Diri (APD). Penggunaan APD bertujuan untuk melindungi diri sendiri yang dalam hal ini merupakan petugas kesehatan dan juga untuk melindungi pasien dari invasi mikroba patogen. APD yang sering dijumpai di RS antara lain berupa sarung tangan, masker, google (kacamata pelindung), face shield (pelindung wajah), dan juga jubah. APD ini digunakan sesuai indikasinya dari tiaptiap jenis APD (Kemenkes RI, 2017). Setiap ruang di rumah sakit sudah dilengkapi dengan Standar Prosedur Operasional (SOP) terkait penggunaan APD.

Penggunaan APD pada perawat masih dikategorikan kurang. Siburan (2012) menunjukkan bahwa sikap perawat dalam penggunaan APD masih kurang, yaitu sebanyak $53,30 \%$ perawat memiliki sikap negatif dan $46,7 \%$ yang memiliki sikap positif. Ningsih (2014) menemukan bahwa perilaku penggunaan APD yang baik pada perawat hanya sebesar $47,6 \%$ dan sisanya $52,4 \%$ menunjukkan penggunaan APD yang kurang baik.
Hasil audit tim PPI RS di Semarang menunjukkan kepatuhan petugas akan penggunaan APD di ruang perawatan sebesar $75 \%$. Hasil observasi di lapangan pada waktu shift pagi ditemukan sebanyak dua orang perawat tidak menggunakan prinsip steril dan sarung tangan steril pada penggantian balutan luka bersih, tiga orang perawat menggunakan sarung tangan bersih pada saat melakukan pemeriksaan tanda vital, tiga orang perawat tidak menggunakan masker dan apron saat melakukan ganti balutan luka bersih, dan seorang perawat memakai sarung tangan bersih sebanyak dua pasang sekaligus setiap melakukan tindakan.

\section{METODE}

Penelitian ini merupakan jenis penelitian kuantitatif dengan pendekatan deskriptif. Penelitian deskriptif adalah penelitian yang berusaha mendeskripsikan suatu gejala, peristiwa, kejadian yang terjadi saat sekarang (Notoadmojo, 2012). Proses pengambilan data dengan menggunakan metode observasi, yaitu dengan mengamati perilaku perawat sesuai dengan instrumen yang digunakan peneliti. Sampel pada penelitian adalah tindakan yang dilakukan oleh perawat pada saat menggunakan APD, yaitu sebanyak 57 tindakan untuk sarung tangan, tujuh pemakaian masker, dan tiga untuk pemakaian apron. Teknik sampling yang digunakan adalah accidental sampling, dimana semua sampel diambil selama periode waktu 10 hari untuk proses pengambilan data. Instrumen pada penelitian ini menggunakan lembar observasi penggunakan APD sesuai dengan standar prosedur operasional rumah sakit. 
HASIL

Data yang telah terkumpul selanjutnya diolah secara univariat dan disajikan dalam bentuk distribusi frekuensi.

Tabel 1. Kesesuaian Penggunaan Sarung Tangan Saat Melakukan Tindakan Keperawatan

\begin{tabular}{|c|c|c|}
\hline Tindakan & Sesuai & $\begin{array}{l}\text { Tidak } \\
\text { Sesuai }\end{array}$ \\
\hline Ganti balut luka bersih & 0 & 7 \\
\hline Memasukkan Obat IV & 1 & 13 \\
\hline $\begin{array}{l}\text { Merawat luka } \\
\text { trakeostomi }\end{array}$ & 0 & 2 \\
\hline Suction melalui OPA & 1 & 0 \\
\hline $\begin{array}{l}\text { Suction melalui ET dan } \\
\text { trakeostomi }\end{array}$ & 0 & 2 \\
\hline $\begin{array}{l}\text { Melakukan } \quad \text { Elektro } \\
\text { Kardio Grafi (EKG) }\end{array}$ & 0 & 1 \\
\hline Memasang kateter & 2 & 1 \\
\hline Membantu memandikan & 3 & 0 \\
\hline $\begin{array}{l}\text { Melakukan pemeriksaan } \\
\text { tanda-tanda vital }\end{array}$ & 0 & 5 \\
\hline $\begin{array}{l}\text { Melakukan pemasangan } \\
\text { infus }\end{array}$ & 11 & 0 \\
\hline Mengambil sampel darah & 8 & 0 \\
\hline Total & $\begin{array}{c}26 \\
(45,61 \\
\%)\end{array}$ & $\begin{array}{c}31 \\
(54,39 \%)\end{array}$ \\
\hline
\end{tabular}

Data penelitian menunjukkan bahwa sebanyak $54,39 \%$ pemakaian sarung tangan tidak sesuai dengan indikasi. Tindakan yang paling banyak tidak sesuai dalam pemakaian tindakan adalah memasukkan obat melalui IV (22,89\%), sedangkan tindakan yang sesuai dalam pemakaian sarung tangan adalah tindakan pemasangan infus $(19,29 \%)$
Tabel 2. Kesesuaian Penggunaan Masker dan Apron

\begin{tabular}{lcc}
\hline \multicolumn{1}{c}{ Tindakan } & Sesuai & Tidak Sesuai \\
\hline Masker & $7(87,5 \%)$ & $1(12,5 \%)$ \\
\hline Apron & $3(100 \%)$ & 0 \\
\hline
\end{tabular}

Berdasarkan pada tabel 2 didapatkan data bahwa sebagian besar perawat sudah sesuai dalam pemakaian masker dan apron sesuai dengan indikasi yang ada.

Tabel 3. Indikasi Penggunaan Masker

\begin{tabular}{clc}
\hline Tindakan & \multicolumn{1}{c}{ Indikasi } & Total (\%) \\
\hline \multirow{2}{*}{ Masker } & Ganti balut & $6(75 \%)$ \\
\cline { 2 - 3 } & Sakit & $1(12,5 \%)$ \\
\cline { 2 - 3 } & $\begin{array}{l}\text { Merawat Pasien } \\
\text { airbone disease }\end{array}$ & $1(12,5 \%)$ \\
\hline
\end{tabular}

Tabel 3 didapatkan data bahwa sebagian besar perawat menggunakan masker untuk tindakan ganti balut dan indikasi yang lain adalah pada saat merawat pasien dengan airbone disease dan pada saat perawat dalam kondisi sakit.

\section{PEMBAHASAN}

Praktik kepatuhan perawat ruang perawatan dalam menggunakan sarung tangan sudah cukup baik. Terdapat beberapa perawat yang masih kurang tepat dalam pemilihan penggunaan APD sehingga masih berisiko membuat pasien terpapar HAIs. Penggunaan APD yang paling banyak ditemukan kekeliruannya adalah penggunaan sarung tangan. Kesalahan perawat dalam menggunakan sarung tangan antara lain, menggunakan sarung tangan bersih untuk tindakan keperawatan yang membutuhkan sarung tangan steril, dan juga menggunakan sarung tangan untuk tindakan yang tidak 
membutuhkan sarung tangan karena tidak berisiko untuk terkena darah dan cairan tubuh (WHO, 2015). Tindakan tersebut misalnya adalah membagikan obat oral, melakukan pemeriksaan tanda-tanda vital, dan juga memberikan injeksi melalui selang infus (intravena). Apalagi perawat hanya menggunakan satu pasang sarung tangan untuk banyak pasien tanpa melakukan cuci tangan atau disinfeksi setelahnya. Urban (2016) menjelaskan bahwa hal tersebut jika berlangsung terus menerus dapat menyebabkan kontaminasi silang.

Rumah sakit mempunyai buku SOP tersendiri yang berisikan antara lain adalah standar alat dan langkah-langkah tindakan tindakan keperawatan. Dari hasil observasi, didapatkan lima orang perawat melakukan ganti balut luka bersih menggunakan sarung tangan bersih dan empat orang perawat menggunakan sarung tangan lebih dari sepasang saat melakukan ganti balut. Dua orang perawat juga masih menggunakan sarung tangan bersih untuk tindakan suction, endotracheal tube (ET), dan trakeostomi, dan seorang perawat menggunakan sarung tangan bersih untuk pemasangan kateter urin. Hal tersebut tidak sesuai dengan SOP rumah sakit yang mencantumkan standar alat berupa sarung tangan steril untuk tindakan-tindakan tersebut. (Kemenkes RI, 2017; WHO, 2016).

Geller tentang safety triad dalam Notoadmojo (2010) menyatakan bahwa membentuk budaya selamat terdapat tiga komponen yang saling berhubungan yaitu person, behavior dan environment. Komponen person merupakan orang yang terlibat langsung dalam hal ini perawat yang dapat dipengaruhi beberapa faktor yaitu pengetahuan, kemampuan, ketrampilan, motivasi dan kepribadian tenaga kerja. Komponen behavior sangat dipengaruhi oleh pengetahuan dan sikap seseorang. Komponen environment merupakan faktor lingkungan seperti sarana dan prasarana yang membantu dalam berperilaku.

Faktor ketidaksesuaian dalam penggunaan APD dapat dipengaruhi oleh faktor environment seperti ketersediaan APD. Kekurangan APD seperti sarung tangan steril yang seharusnya digunakan untuk melakukan tindakan bersifat aseptik seperti suction melalui ET dan ganti balutan luka operasi seperti luka laparatomi dan kraniotomi menjadi kendala utama dalam menggunakan APD yang tepat untuk tindakan tersebut. Perawat seharusnya dapat mempersiapkan ketersediaan APD tersebut saat perawat mengetahui kondisi pasien di hari perawatan sebelumnya, dan meresepkan APD tersebut ke bagian farmasi rumah sakit. Hal tersebut dapat mengantisipasi kekurangan jumlah APD yang tepat seperti sarung tangan steril saat akan melakukan tindakan.

Kepatuhan perawat menggunakan APD yang tepat harus ditingkatkan untuk mencegah infeksi pada daerah operasi pasien. Walaupun sudah terdapat SOP dan regulasi yang jelas, nyatanya memang masih banyak perawat yang mengabaikan teknik aseptik pada tindakan yang harusnya bersifat aseptik. Padilha et al. (2016) menyebutkan sebanyak 22\% perawat masih tidak menggunakan sarung tangan steril untuk tindakan aseptik, sehingga berpotensi meningkatkan angka surgical site infection (SSI).

$$
\text { Padilha et al. }
$$

mengungkapkan bahwa $84 \%$ perawat di Brazil mengerti dengan benar jenis sarung tangan apa yang harus digunakan, kapan harus menggunakannya, bagaimana 
memakainya, dan bagaimana melepasnya. Namun pada praktiknya, pengetahuan tersebut tidak diaplikasikan sepenuhnya dalam praktik keseharian perawat saat melakukan asuhan keperawatan kepada pasien. Sebanyak $28 \%$ responden tidak tepat menggunakan sarung tangan yang tepat dikarenakan kebiasaan, $22 \%$ mengatakan dengan alasan kualitas sarung tangan yang buruk, 20\% karena kurangnya kepedulian akan sikap aseptik, dan 13\% karena terburu-buru saat bekerja dan tidak sempat untuk menggunakan jenis sarung tangan yang tepat. Tahap perencanaan menjadi penting, karena dalam tahap perencanaan perawat akan tahu alat apa saja yang dibutuhkan oleh pasien untuk tindakan intervensi keperawatan.

Motivasi dan faktor emosional perawat sangat berkaitan dengan kepatuhan seorang perawat dalam menggunakan APD yang tepat saat melakukan tindakan. Kekeliruan penggunaan sarung tangan tidak lepas dari motivasi perawat dalam melakukan hal yang tepat, serta emosi yang saat itu sedang dirasakan perawat. Loveday, Lynam, Singleton, dan Wilson (2014) menyatakan hal yang mempengaruhi penggunaan sarung tangan antara lain adalah rasa takut dan jijik. Rasa takut berhubungan dangan ketakutan perawat akan terkena cairan tubuh atau tertular penyakit pasien. Rasa jijik berhubungan dengan rasa enggan untuk bersentuhan dengan darah, luka, kotoran pasien ataupun mencium aroma yang tidak sedap yang mungkin berasal dari tubuh pasien. Hal lain yang mempengaruhi penggunaan sarung tangan oleh tenaga kesehatan adalah tekanan dari teman sejawat ataupun peraturan yang berlaku, dan juga norma sosial (Loveday, Lynam, Singleton,
\& Wilson, 2014).

Penyalahgunaan yang berarti tidak ditemukan dalam penggunaan APD lainnya yaitu masker dan apron. Perawat sudah menggunakan masker kurang lebih dengan alasan yang tepat, seperti perawat sedang sakit sehingga menghindari penularan dari perawat ke pasien, atau perawat sedang melakukan tindakan ganti balut luka bersih ataupun kotor, dimana dalam SOP tindakan keperawatan memang tercantumkan bahwa perawat dapat menggunakan masker. Perawat juga menggunakan masker saat berinteraksi dengan pasien yang diduga menderita penyakit airborne disease seperti suspect tuberculosis dan juga pasien yang sedang batuk atau flu. Hanya ditemukan seorang perawat yang memakai masker lalu menurunkannya sebatas leher dengan tujuan agar dapat berkomunikasi dengan lebih jelas. Hal itu membuat masker menjadi kehilangan fungsinya karena tidak menutupi hidung ataupun mulut.

Masker bedah sebagai APD harus memenuhi kriteria sebagai berikut: kedap air agar dapat mencegah cairan masuk ke mulut atau hidung, dan harus menempel sempurna dan erat di sekitar mulut dan hidung. Masker juga harus fleksibel dalam pemakaiannya, inilah mengapa masker mempunyai bagian keras fleksibel yang berada di bagian yang menemel dengan hidung dan dapat disesuaikan oleh penggunanya. Dalam teknik pelepasan, pengguna masker bedah juga dihimbau agar tidak menyentuh bagian depan dari masker dimana bagian tersebut dianggap bagian yang infeksius. Penggunaan yang tidak tepat dapat menyebabkan pengguna berisiko menghirup aerosol yang bersifat infeksius (CDC, 2015).

Penggunaan apron di ruangan juga sudah sebagaimana mestinya. Perawat 
menggunakan apron untuk melindungi tubuh dari percikan darah, cairan tubuh pasien, ataupun kotoran. Apron sudah tepat digunakan saat memandikan pasien, mengganti kantong kolostomi dan juga mengganti balutan kotor. Apron yang digunakan di ruangan merupakan apron plastik sekali pakai sehingga setelah apron digunakan langsung dibuang ke tempat sampah infeksius. Hal tersebut pun sudah dilakukan oleh perawat dengan tepat.

Ortega et al. (2015) menyebutkan apron sebagai APD harus digunakan dengan benar. Penggunaan yang tepat adalah apron harus bersifat tahan air, digunakan menutupi dada hingga di bawah lutut, terikat dengan baik. Penggunaan apron sangat direkomendasikan sebagai langkah antisipasi dalam menangani pasien dengan diare dan muntah. Hal ini dilakukan karena pasien dengan diare dan muntah seringkali mengeluarkan cairan tubuh dengan tiba-tiba.

Sosialisasi perlu ditingkatkan sehubungan dengan adanya masalah terkait penggunaan APD. Sosialisasi SOP penggunaan APD yang tepat bagi perawat terbukti dapat meningkatkan kesadaran perawat akan penggunaan APD yang tepat, sehingga dapat meminimalisir angka kejadian infeksi baik dari perawat ke pasien maupun sebaliknya. Sebelum dilakukan sosialisasi, perilaku perawat tentang APD mempunyai skor tujuh, dan setelah enam hari diberi sosialisasi tentang SOP penggunaan APD perilaku perawat akan penggunaan APD mempunyai skor sembilan. Hal ini membuktikan bahwa perawat walaupun diyakini telah terpapar edukasi yang benar mengenai APD dan penggunaannya, masih membutuhkan sosialisasi secara rutin dan mendalam agar tetap menjaga perilaku dan kepatuhan terkait penggunaan APD di rumah sakit (Sari, 2016).

Ketersediaan APD seperti sarung tangan bersih, masker, dan apron di dalam ruangan sudah cukup baik, hanya saja untuk APD jenis-jenis tertentu seperti sarung tangan steril, memang disediakan sesuai dengan keperluan tiap-tiap pasien. Perawat ruangan terkadang lupa untuk meresepkan sarung tangan steril yang dibutuhkan oleh pasien saat tindakan keperawatan tertentu. Hal ini membutuhkan koordinasi yang baik antara kepala ruang, perawat penanggung jawab pasien (PPJP), dan IPCLN untuk memotivasi perawat pelaksana agar lebih cermat memahami kebutuhan tindakan keperawatan yang dibutuhkan oleh pasien. Hal ini untuk mencegah terjadinya kekurangan APD yang sesuai untuk pasien, dan dalam tentu juga untuk menghindari kontaminasi silang pada pasien.

\section{KESIMPULAN DAN SARAN}

Berdasarkan uraian diatas dapat ditarik kesimpulan bahwa sebagian besar perawat dalam melakukan tindakan keperawatan masih tidak sesuai dalam penggunaan sarung tangan. Pemakaian masker dan apron sudah sesuai dengan indikasi dan SPO ruangan. Penelitian selanjutnya disarankan untuk meneliti faktor-faktor yang berhubungan dengan kepatuhan perawat dalam penggunaan APD. 


\section{DAFTAR PUSTAKA}

Centre for Disease Control and Prevention. (2015). Personal protective equipment. Diperoleh dari https://www.cdc.gov/niosh/topics/e mres/ppe.html

Jeyamohan, D. (2010). Angka prevalensi infeksi nosokomial pada pasien luka operasi pasca bedah di Bagian Bedah di Rumah Sakit Umum Pusat Haji Adam Malik, Medan dari Bulan April sampai September 2010. Universitas Sumatera Utara. Diperoleh dari http://repository.usu.ac.id/handle/1 23456789/21521

Kementerian Kesehatan Republik Indonesia. (2017). Peraturan Menteri Kesehatan Nomor 27 tentang Pedoman Pencegahan dan Pengendalian Infeksi di Fasilitas Pelayanan Kesehatan.

Loveday, H. P., Lynam, S., Singleton, J., \& Wilson, J. (2014). Clinical glove use: Healthcare workers' actions and perceptions. Journal of Hospital Infection, 86(2), 110-116. doi: $10.1016 /$ j.jhin.2013.11.003

Ningsih, S. S. R. (2014). Gambaran perilaku perawat dalam penggunaan alat pelindung diri di ruang rawat inap Rumah Sakit Umum Daerah Kota Bandung. (Tugas Akhir D3). Diperoleh dari http://repository.upi.edu/15871/

Notoadmojo, S. (2012). Metodologi penelitian kesehatan. Jakarta: Rineka Cipta.
Notoadmojo, S. (2010). Ilmu perilaku kesehatan. Jakarta: Rineka Cipta.

Nugraheni, R., Suhartono, Winarni, R. (2012). Infeksi nosokomial di RSUD Setjonegoro Kabupaten Wonosobo. Media Kesehatan Masyarakat Indonesia, 11(1), 94100.

Ortega. R., Bhadelia, N., Obanor, O., Cyr, K., Yu, P., McMahon, M.,...Gotzmann, D. (2015). Putting on and removing personal protection equipment. The New England Journal of Medicine, 16(372). doi: 10.1056/NEJMvem1412105.

Padilha, J. M. F., Sá, S. P. C., de Souza, S. R., Brum, A. K., Lima, M. V. R. L., \& Guimarães, T. F. (2016). Glove use in nursing practice and its implications: A methodological study. Online Brazilian Journal of Nursing, 15(4).

Sari, R. Y. (2016). Pengaruh Sosialisasi SOP PAD dengan perilaku perawat dalam penggunaan APD di RSUD H. Soewondo. (Skripsi). Program Studi S1 Ilmu Keperawatan STIKES Telogorejo, Semarang.

Siburian, A. 2012. Gambaran penggunaan alat pelindung diri (APD) terhadap keselamatan kerja perawat IGD RSUD Pasar Rebo Jakarta. (Skripsi). Diperoleh dari http://lib.ui.ac.id/file?file=digital/20 310394-S43080-

Gambaran\%20penggunaan.pdf

Urban, J. (2016). Press release: contaminated gloves increase risk of cross-transmission of healthcare 
associated pathogens. Diperoleh

dari

https://www.asm.org/index.php/ne

wsroom/item/5559-contaminated-

gloves-increase-risks-of-cross-

transmission-of-healthcare-

associated-pathogens.

World Health Organization. (2015).

Gloves use information leaflet.

Diperoleh dari

https://www.who.int/gpsc/5may/Gl

ove_Use_Information_Leaflet.pdf

World Health Organization. (2016). Guidelines on core components of infection prevention and control programmes at the national and acute health care facility level. Geneva. 